\title{
Environmental Influences on Caribbean Fish Catch
}

\author{
Mark R. Jury ${ }^{1,2}$ \\ ${ }^{1}$ Department of Physics, University of Puerto Rico Mayagüez, PR 00681, Puerto Rico \\ ${ }^{2}$ University of Zululand, KwaDlangezwa 3886, South Africa \\ Correspondence should be addressed to Mark R. Jury, mark.jury@upr.edu \\ Received 30 September 2010; Revised 24 January 2011; Accepted 19 February 2011 \\ Academic Editor: Grant Bigg
}

Copyright (๑) 2011 Mark R. Jury. This is an open access article distributed under the Creative Commons Attribution License, which permits unrestricted use, distribution, and reproduction in any medium, provided the original work is properly cited.

A Caribbean fishery index is used to identify contrasting environmental conditions in atmosphere and ocean reanalysis fields associated with high- and low-catch years over the period 1971-2004. A number of composite features are noted: cooler surface temperatures and warmer, drier weather across the southern half of the Caribbean favors higher catch rates. There is a ridge of elevated sea level on $16^{\circ} \mathrm{N}$. South of the ridge the Caribbean Current is strengthened while north of the ridge anomalous eastward currents flow past the Antilles Islands. The atmospheric Hadley circulation weakens in years of high catch and tropical cyclones are rare. This paper uncovers basin-scale forcing of aggregate fish catch, reflecting a north-south gradient in land-atmosphere hydrology, and composite oceanographic differences based on reanalysis data. In addition, seasonal and interannual cycles of ocean productivity are investigated using satellite ocean color. Summertime upwelling along the coast of Venezuela joins fresher waters from the North Brazil Current to infuse the Caribbean ecosystem with higher nutrients.

\section{Introduction}

The Caribbean Sea is a semienclosed basin bounded on the south and west by South and Central America and on the east and north by the chain of Antilles Islands $\left(8^{\circ} \mathrm{N}-25^{\circ} \mathrm{N}\right.$, $\left.85^{\circ} \mathrm{W}-55^{\circ} \mathrm{W}\right)$. Persistent trade winds, solar insolation and tropical water exchanges limit seasonal variations in surface temperatures $\left(25^{\circ}-28^{\circ} \mathrm{C}\right)$. The thermocline is $\sim 200 \mathrm{~m}$ deep and the upper $1200 \mathrm{~m}$ is stratified [1-3]. Several gaps between eastern islands (Grenada, St Vincent, St Lucia) are passes for ocean currents connecting with the Atlantic Ocean $[4,5]$. From there, water flows across the Caribbean Sea as a meandering westward current reaching a surface velocity of $0.7 \mathrm{~m} / \mathrm{s}$ along $14^{\circ} \mathrm{N}$ [6-9]. The current passes the Nicaragua Rise southwest of Jamaica, with a branch forming the counterclockwise Panama Gyre $[5,10,11]$ and the bulk exiting via the Yucatan Channel. The Gulf Stream near Florida is joined by the Antilles Current that transports Atlantic waters northwestward around the Caribbean [1214]. Schmitz and Richardson [15] and Johns et al. [4] find $\sim 28 \mathrm{~Sv}$ of throughflow in the Caribbean from both North and South Atlantic sources [16]. South Atlantic waters are fresher and more oxygenated than North Atlantic waters of the same density, and enter the Caribbean north of Trinidad next to the Orinoco plume [17]. While the mean structure of water masses and currents in the Caribbean is well known and processes underlying year-to-year fluctuations are being uncovered [18], basin-scale impacts on fish catch are relatively unknown.

Tropical fishery abundance has been linked to coral reef environments with adequate food sources [19-21]. Trade winds that blow across the Caribbean establish basin-scale currents that are modulated by islands, offering chances for recirculation and biological retention [22-27]. Greater currents and turbulence in exposed open seas tends to scatter food sources [28-32]. In the Caribbean most spawning is during spring when sea surface temperatures (SST) are cooler [33-36], particularly along the Caribbean's southern edge, where coastal upwelling contributes to higher productivity ([34, 37-39] cf. Figures 1(d), 1(e), and 1(f)).

Low salinity and high turbidity associated with river discharges can have localized impacts on fisheries. The Orinoco plume in eastern Venezuela spreads across the southern Antilles area $\left(>10^{6} \mathrm{~km}^{2}\right.$, Muller-Karger et al. [17, $40,41]$ ). At varying distances downstream river plumes can be a source of nutrients or pollutants, and a mechanism for transport and stratification, producing convergence fronts 


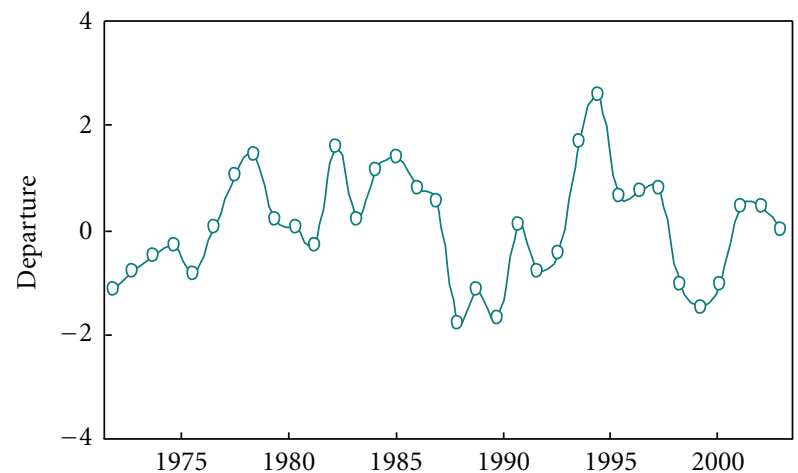

(a)

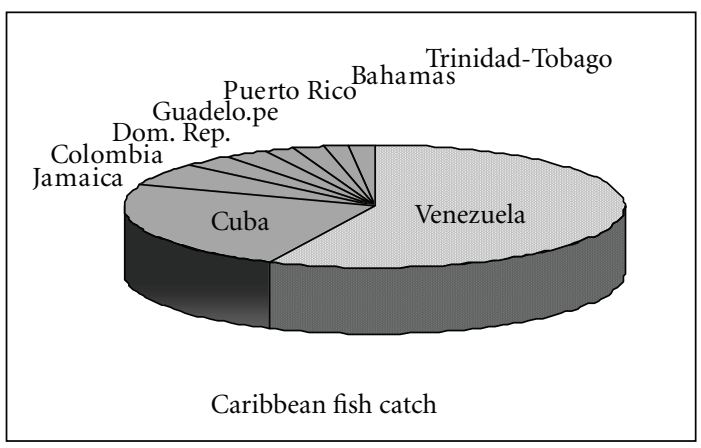

(c)

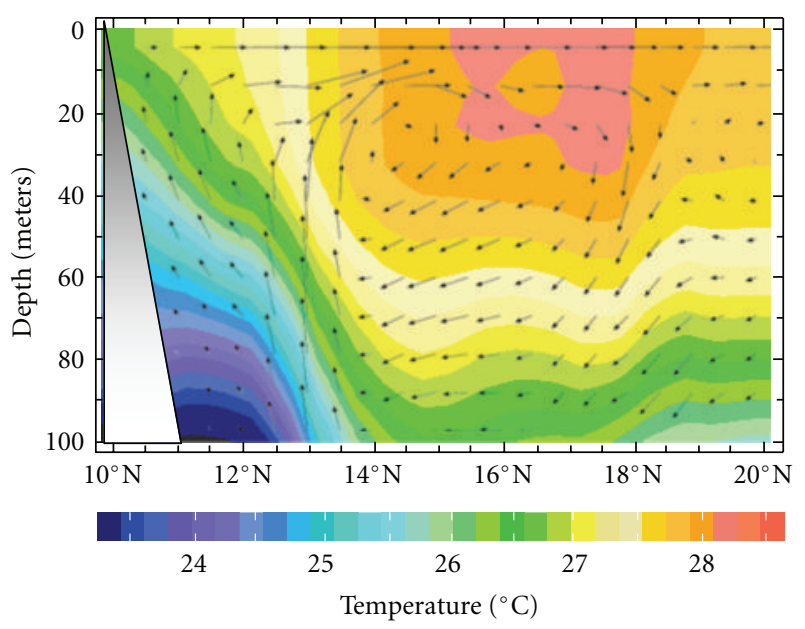

(e)

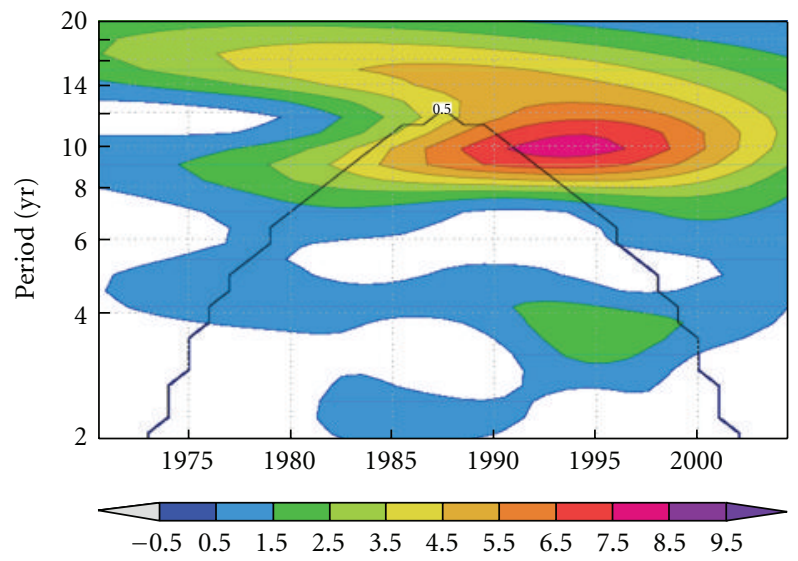

(b)

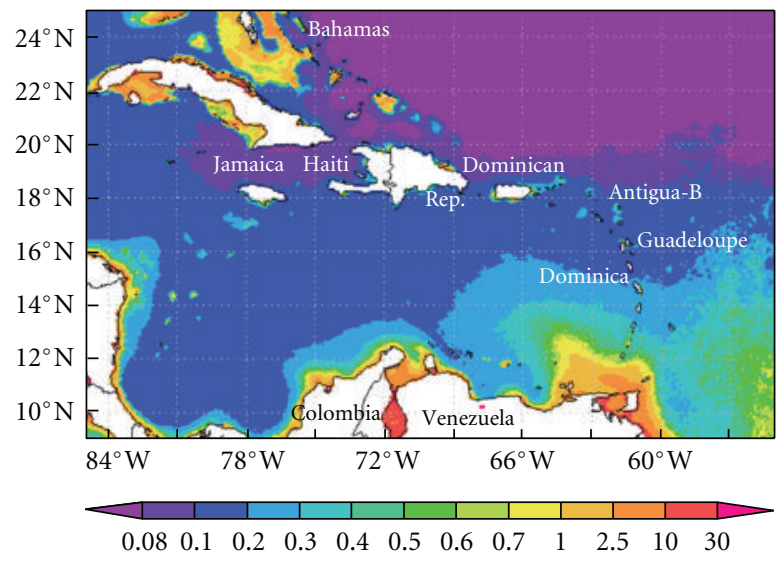

(d)

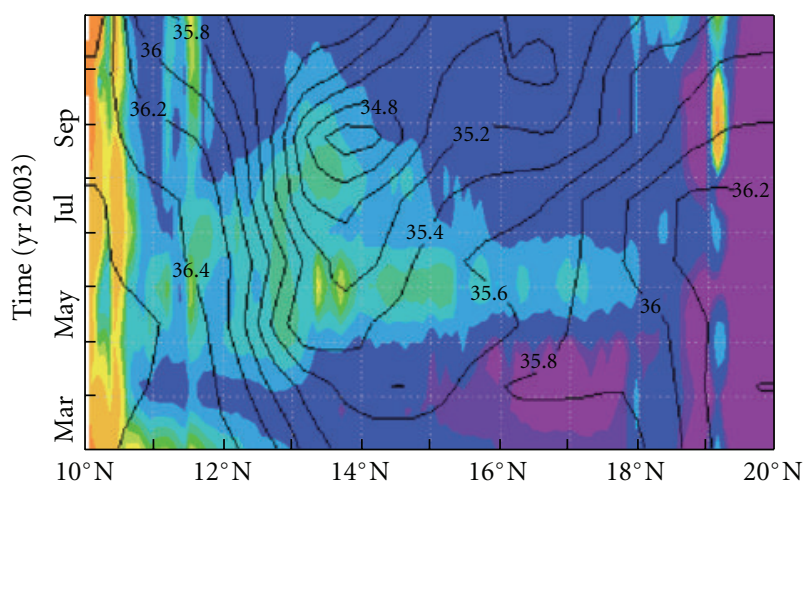

(f)

FIGURE 1: (a) Caribbean fish catch index time series, where $1 \sigma=92280 \mathrm{~T} / \mathrm{yr}$ and (b) its wavelet spectrum with cone of validity and power shaded. (c) Caribbean country fish catch ranked by weight-excluding lesser, (d) satellite mean chlorophyll ( $\left.\mathrm{mg} / \mathrm{m}^{3}\right)$ with countries in the catch index labelled. (e) Depth section of sea temperature and vertical overturning circulation north of Venezuela averaged March-October 2003, (f) latitude-time hovmöller of chlorophyll (shaded, as in (d)) and salinity ( $\mathrm{g} / \mathrm{kg}$ ) for the same period averaged 65-70 W. 


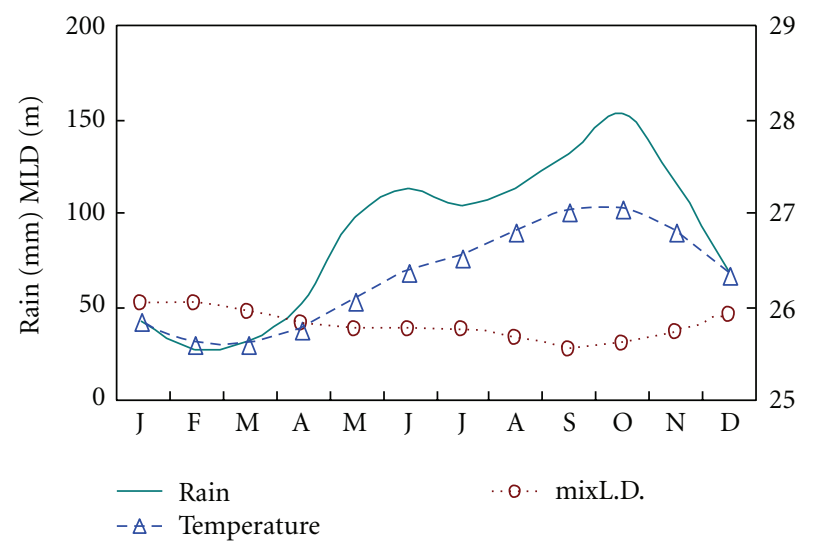

(a)

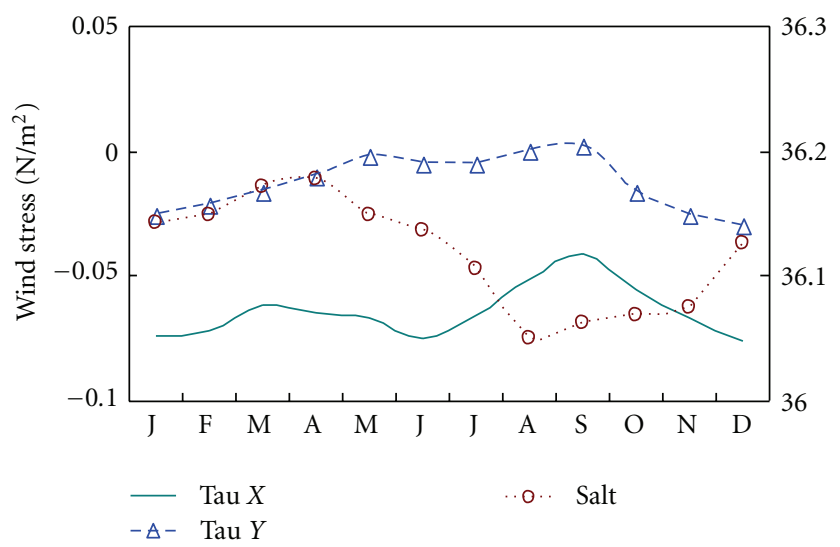

(c)

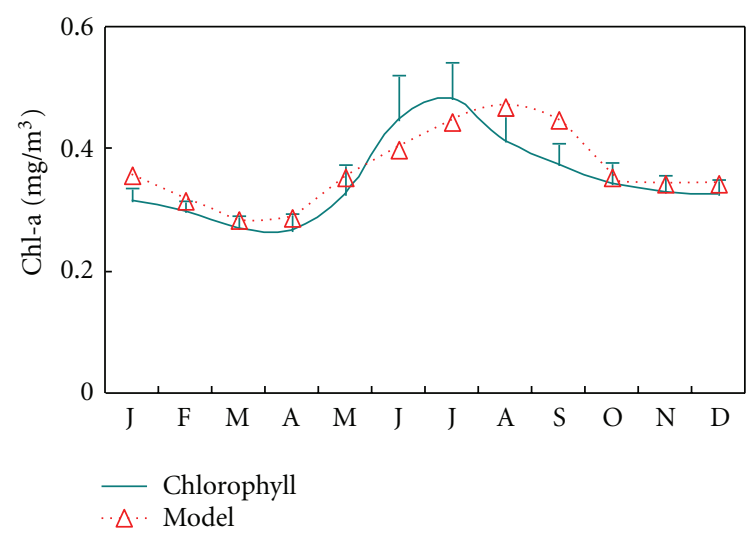

(e)

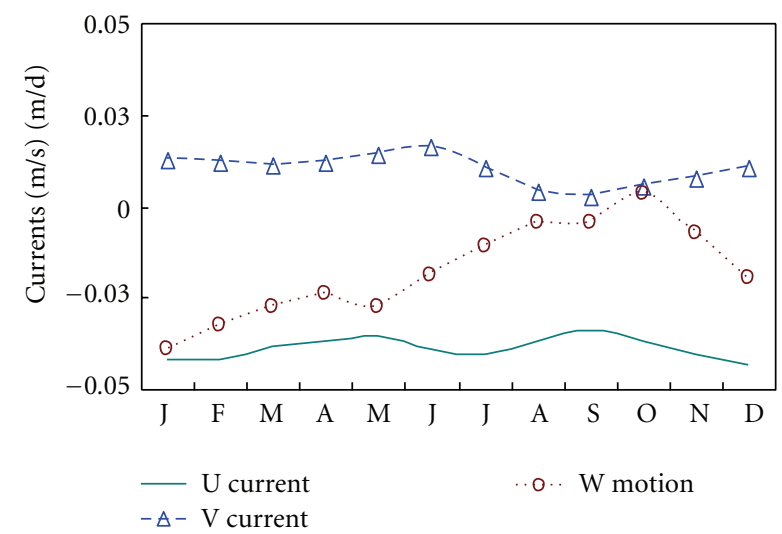

(b)

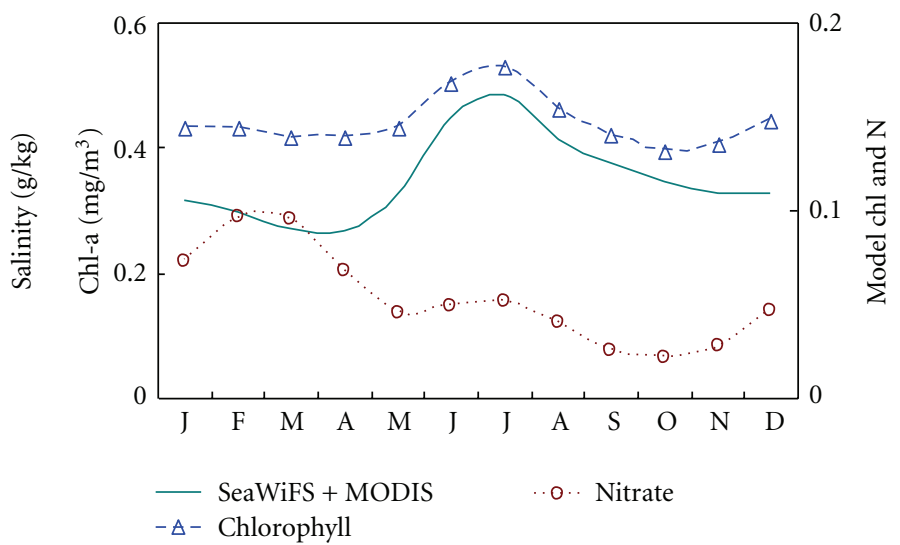

(d)

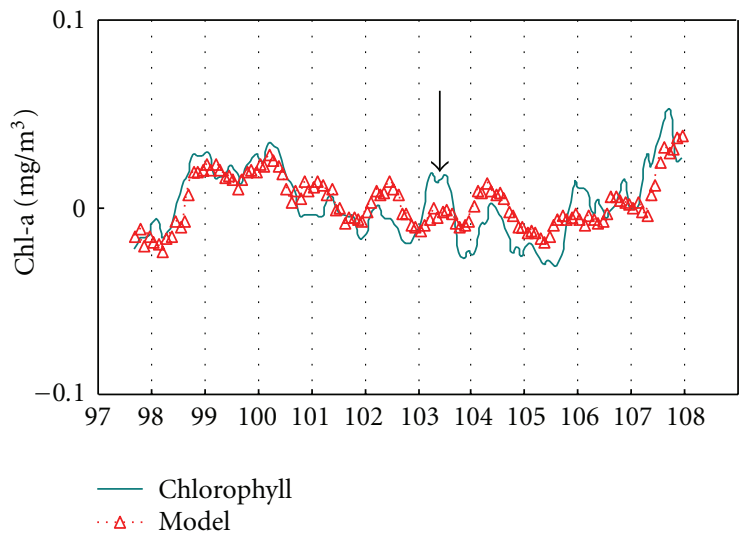

(f)

FIGURE 2: Caribbean area seasonal cycle for (a) rain, mixed layer depth and 0-100 $\mathrm{m}$ temperature, (b) 0-200 m zonal/meridional currents and vertical motion, (c) zonal/meridional wind stress and 0-50 m salinity, (d) SeaWifs chlorophyll, chlorophyll and nitrate from NOBM model, (e) chlorophyll with deviations and multivariate model. (f) Smoothed monthly SeaWifs chlorophyll anomaly and multivariate model as in Table 2, with pointer to event in Figures 1(e) and 1(f).

that aggregate plankton and fish [42-44]. While long-term mean ocean currents act as pathways for population connectivity, they exhibit eddies and gyres [45-48]. Drifters and profiling floats reveal much flow variability in the Caribbean, often moving across or looping around the mean flow [49]. Leeward of oceanic islands nutrient enrichment is often seen due to runoff and wind-induced upwelling, leading to greater zooplankton biomass [50-52] that provide food sources in oligotrophic waters such as the northern Caribbean.

This literature survey highlights some of the factors influencing tropical fisheries. Winds, currents, water stratification and nutrient levels vary on different time and space scales, and can produce irregular cycles in marine resources, notwithstanding changes in fishing effort and consumption. 
To understand how the environment modulates fish catch it is necessary to analyze the subsurface ocean, and with the advent of global ocean monitoring and reanalysis products, new tools are available. While past work on the fishery biology is usually focused at local level over the lifespan of individual species, the approach here is to uncover basinscale influences on the aggregate fishery during the catch year. Given the uneven distribution of historical ocean observations, evidence of biologically influential conditions may be elusive unless suitable methods are employed. Here a composite technique is used to quantitatively contrast reanalysis fields in high- and low-catch years. The key questions which are addressed include: What are the key environmental features that distinguish high- and lowcatch years? Are these features significant in the context of natural variability? Is ocean-atmosphere coupling evident? Do conditions relate to catch effort or nutrification? Are the key features having north-south or east-west gradients? and, Does the surface hydrology play an important role?

\section{Data and Methods}

A fishery index was developed by gathering catch records for all Caribbean countries (excluding Central America) from the website: http://www.fishbase.us/ [53] over the period 1971-2004. There are known reporting problems associated with commercial catch records $[54,55]$, so annual data as an aggregate for all species were extracted for each country by weight and also as standardized departures: subtracting the mean and dividing the standard deviation for each. The totalby-weight favors countries with longer coastlines and bigger catch (e.g., Venezuela, cf. Figure 1(c)), while standardized departures ensure equal representation (spreading the risk of uneven reporting). Individual country data were then crosscorrelated with the two series and those with significant values (Table 1) were retained to form a Caribbean fish catch index by averaging the standardized departures. Next the linear upward trend related to increasing effort [56] was removed. The annual detrended standardized fish catch values were then ranked. Years with fish catch $>+1 \sigma$ and $<-1 \sigma$ were identified: seven of each. The mean difference between high- and low-catch is $\sim 200000 \mathrm{~T} / \mathrm{yr}$, about half the total. To aggregate the environmental data and reduce the number of maps/sections for interpretation, composite averages were made for the high catch years and the lowcatch years, and the low field was subtracted from the high field to contrast environmental conditions. The composites draw 14 years of observations into a single field-limiting problems of sparse subsurface observations.

Atmospheric conditions are represented by the National Center for Environmental Prediction (NCEP) reanalysis product [57]. These monthly gridded fields at $2^{\circ}$ horizontal and $500 \mathrm{~m}$ vertical resolution are based on surface ship and coastal observations, radiosonde profiles and aircraft reports, and satellite remote sensing of clouds, temperature, humidity and winds; all of which are optimally interpolated using a numerical weather prediction model. Because the ocean is affected by fresh water inputs from the land and
TABLE 1: Correlation values of individual country fish catch with respect to the all-Caribbean total by weight and by standardized departure over the period 1971-2004. For $=34, r>0.27$ significant at $90 \%$ confidence (bold number and country).

\begin{tabular}{lcc}
\hline By weight & By sigma & Country \\
\hline $\mathbf{0 . 3 6}$ & $\mathbf{0 . 3 7}$ & Antig-Barbuda \\
-0.74 & 0.06 & Aruba \\
$\mathbf{0 . 8 6}$ & $\mathbf{0 . 3 0}$ & Bahamas \\
-0.53 & 0.08 & Barbados \\
$\mathbf{0 . 6 1}$ & $\mathbf{0 . 4 2}$ & Colombia \\
$\mathbf{0 . 2 8}$ & 0.25 & Dominica \\
$\mathbf{0 . 6 5}$ & 0.06 & Dominican Rep. \\
-0.36 & -0.33 & Grenada \\
-0.43 & $\mathbf{0 . 5 2}$ & Cuba \\
$\mathbf{0 . 6 1}$ & $\mathbf{0 . 4 9}$ & Guadeloupe \\
$\mathbf{0 . 4 4}$ & 0.08 & Haiti \\
$\mathbf{0 . 6 8}$ & 0.23 & Jamaica \\
0.21 & 0.02 & Martinique \\
0.05 & 0.14 & Neth.Antilles \\
-0.35 & 0.25 & Puerto Rico \\
-0.82 & $\mathbf{0 . 3 9}$ & StKitts/Nevis \\
-0.17 & $\mathbf{0 . 3 1}$ & St. Lucia \\
$\mathbf{0 . 2 9}$ & 0.12 & St. Vincent \\
-0.18 & $\mathbf{0 . 3 6}$ & Trinidad-Tob. \\
-0.26 & 0.05 & US Virg.Isl. \\
$\mathbf{0 . 9 5}$ & $\mathbf{0 . 3 1}$ & Venezuela \\
\hline & &
\end{tabular}

atmosphere; rainfall, river gauges and run-off estimates [58] were analyzed.

To describe the oceanographic environment, the monthly SODAv2.4 ocean reanalysis products of the University of Maryland at $0.5^{\circ}$ horizontal and $\sim 20 \mathrm{~m}$ depth resolution are employed [59]. These make use of all hydrographic data (XBT, CTD, ADCP, etc.), optimally interpolated using a numerical ocean model that employs European Community Medium-range Weather Forecast (ECMWF) wind stress and surface fluxes, coastal stations, moored buoys, drifters, and satellite infrared SST (1979+), altimetry (1985+) and wind scatterometry $(1998+)$.

Contrasts in the environmental conditions in years of high- and low-catch were analyzed by field subtraction via the IRI Climate Library website http://iridl. ldeo.columbia.edu/SOURCES/.CARTON-GIESE/SODA/.v2 p0p2-4/ and differences were evaluated for: SST, sea surface height, wind stress, and in depth sections or as depth-averages for temperature, salinity, currents and vertical motion. In addition, composite tracks of tropical cyclones (hurricanes) in the Caribbean were mapped with respect to high- and low-catch years, based on the National Hurricane Center reanalysis product. The annual fish catch index in the period 1971-2004 was analyzed for evolving spectral cycles using wavelet transform via the website: http://ion.researchsystems.com/IONScript/wavelet/. To detemine whether differences in high- and low-catch years are modulated by a naturally occurring mode of ocean climate 


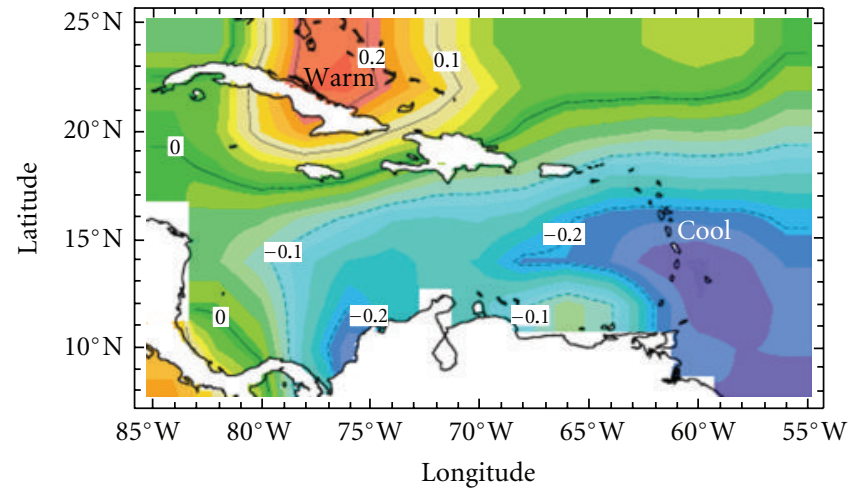

(a)

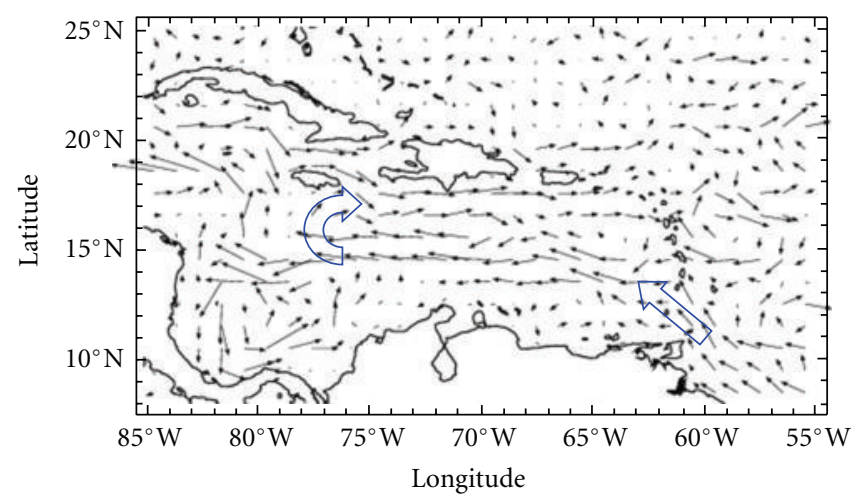

$\longrightarrow 0.1$

(c)

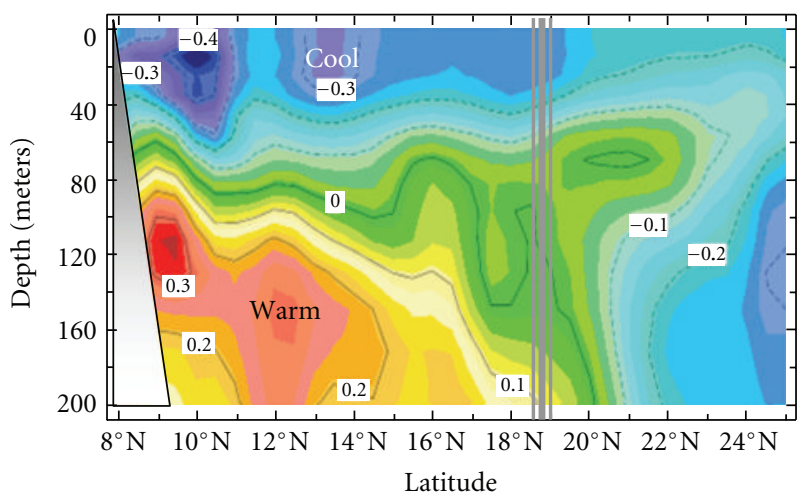

(e)

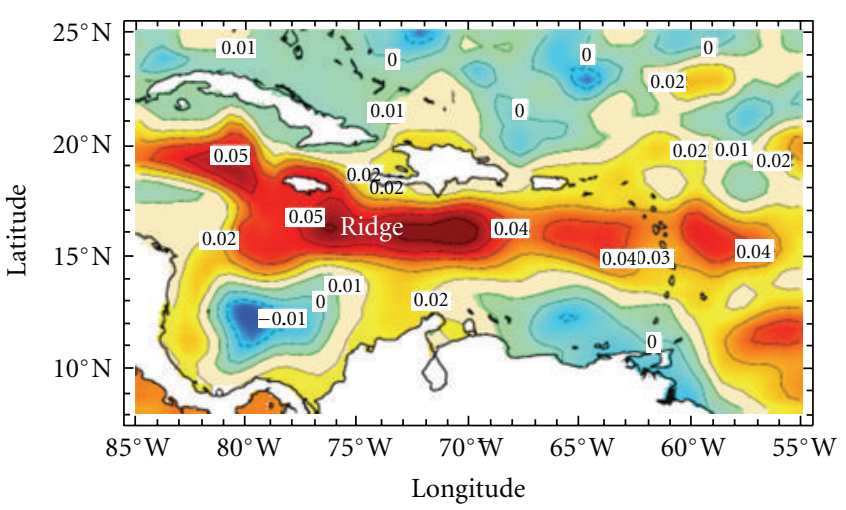

(b)

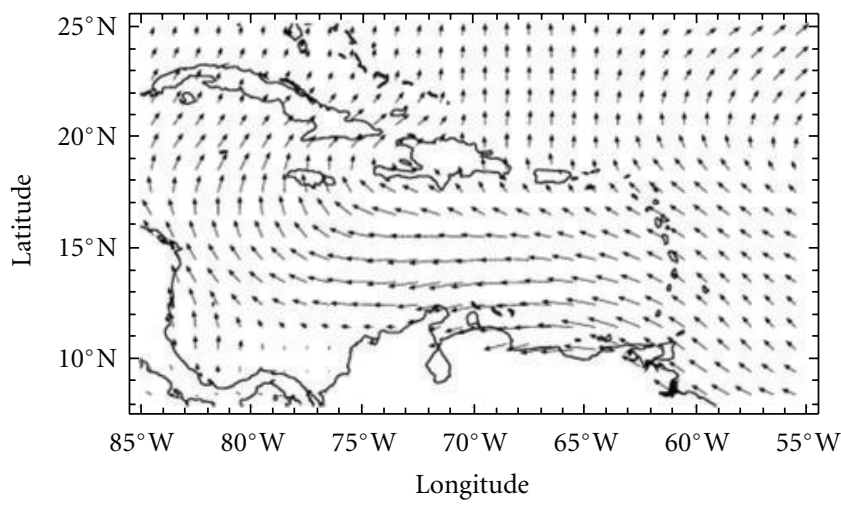

$\longrightarrow 0.01$

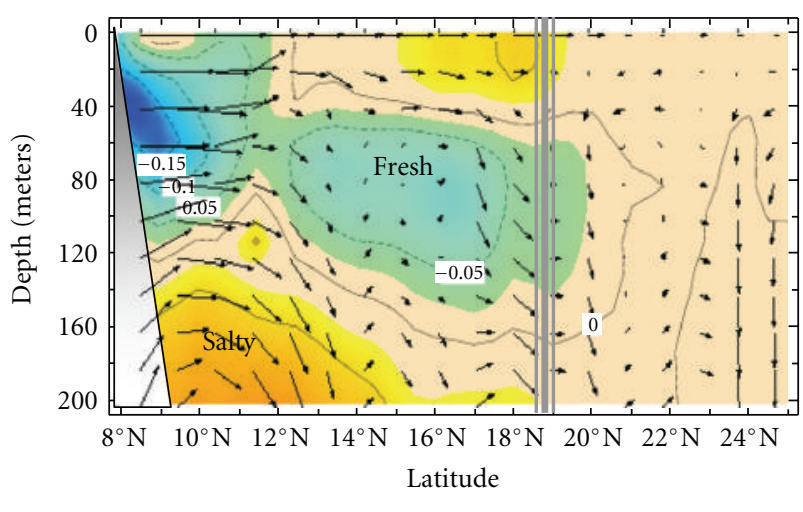

$\longrightarrow 0.01$

(f)

Figure 3: Composite difference maps for (a) SST $\left({ }^{\circ} \mathrm{C}\right)$, (b) sea surface height $(\mathrm{m}),(\mathrm{c})$ 0-200 $\mathrm{m}$ vector currents $(\mathrm{m} / \mathrm{s})$ in respect of high minus low fish catch, and (d) vector wind stress $\left(\mathrm{N} / \mathrm{m}^{2}\right)$. Composite vertical N-S sections of (e) temperature $\left({ }^{\circ} \mathrm{C}\right),(\mathrm{f}) \mathrm{salinity}(\mathrm{g} / \mathrm{kg})$ and $\mathrm{V}$ W currents $(\mathrm{m} / \mathrm{s})$, with vertical motion exaggerated. Vertical bar represents Antilles, South America is left-side of sections. Key vectors are given.

variability, the environmental fields were objectively analyzed by empirical orthogonal function (EOF) decomposition of the covariance matrix, with variability reduced to modes represented by spatial loadings and time scores. The domain of analysis covers the Caribbean from $8^{\circ}-25^{\circ} \mathrm{N}, 85^{\circ}-55^{\circ} \mathrm{W}$ with a focus on the leading mode of $0-200 \mathrm{~m}$ zonal currents and comparison with patterns that relate to the Caribbean fishery.

Given that the fish catch index does not account for changes in effort and may not coincide with abundance, 


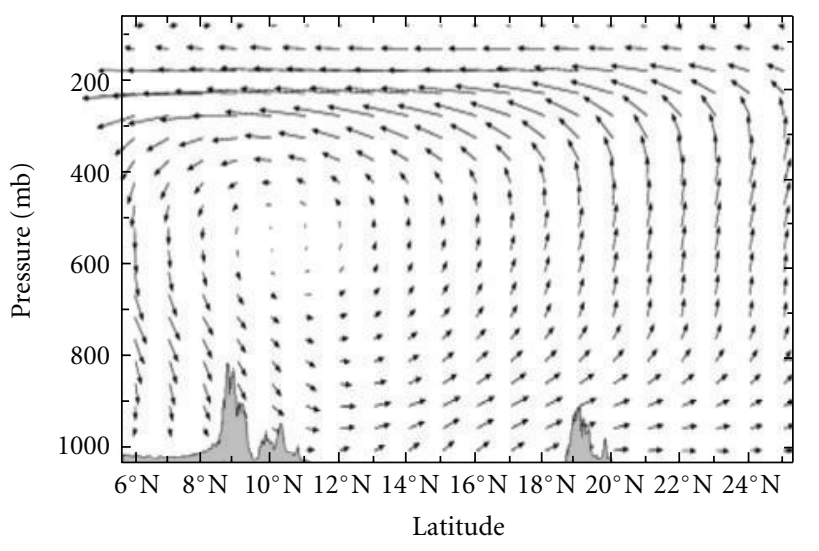

(a)

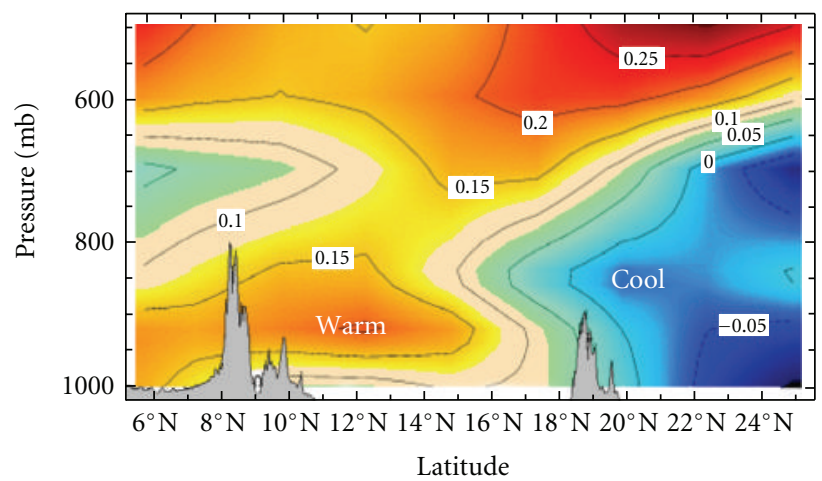

(c)

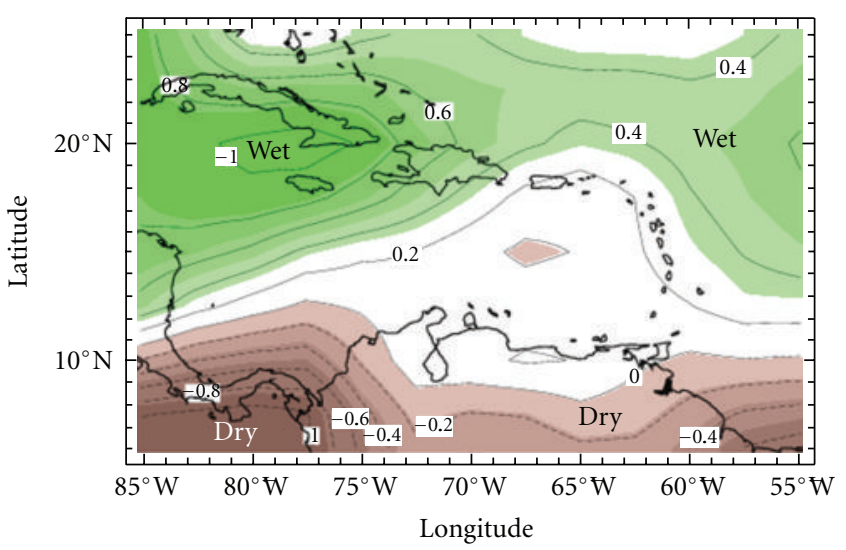

(b)

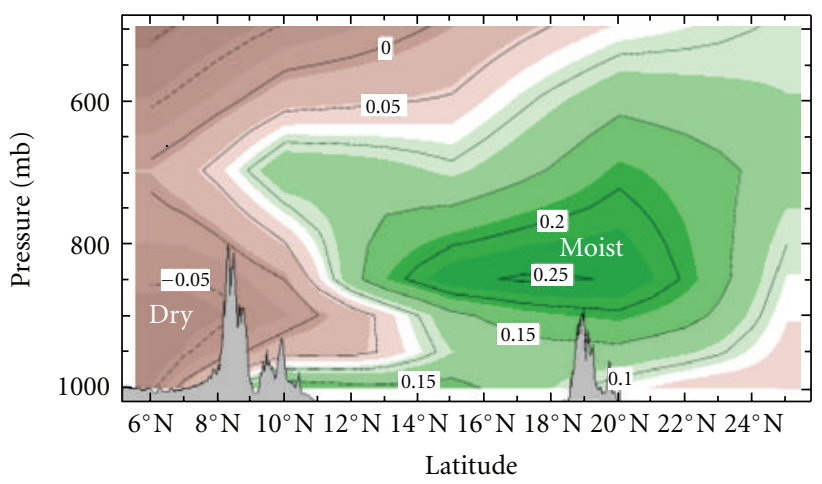

(d)

FIGURE 4: Composite difference height sections of (a) meridional winds and vertical motion (m/s), (c) air temperature $\left({ }^{\circ} \mathrm{C}\right)$, and $(\mathrm{d})$ specific humidity $(\mathrm{g} / \mathrm{kg})$ with land represented. Composite difference map for $(\mathrm{b})$ precipitable water $(\mathrm{mm})$.

an understanding of environmental modulation using an objective measure of productivity is needed. For this, monthly obtained from reason.gsfc.nasa.gov/Giovanni and analyzed in the period 1998-2007 for seasonal cycle and consecutive anomalies. Seasonal cycles were also constructed for rainfall, winds, currents, vertical motion, temperature and salinity, and anomaly time series were smoothed with a 7-month running mean. Further ocean data on chlorophyll, nitrate and mixed layer depth were obtained from the NOBM model [60] averaged over the Caribbean, with a focus on the seasonal cycle. The NOBM model uses a similar reanalysis system as SODAv2.4 and offers additional ocean chemistry and productivity outputs. The environmental variables were regressed onto chlorophyll using the forward stepwise method and an optimal multivariate solution was determined using an objective Statgraphics routine. Statistical significance was evaluated with 8 degrees of freedom (df) for the seasonal cycle and $18 \mathrm{df}$ for the smoothed anomalies.

\section{Results}

3.1. Fish Catch, Seasonal Cycle and Productivity. A statistical intercomparison of individual country fish catch with the Caribbean indices over the period 1971-2004 is listed in Table 1. Those significantly correlated include: Antigua-Barbuda, Bahamas, Colombia, Dominica, Dominican Republic, Guadeloupe, Haiti, Jamaica and Venezuela. Thus 9 of 21 contribute to the Caribbean fish catch index (Figure 1(a)) subsequently considered as a basis for composite analysis. The catch index wavelet spectrum exhibits significant oscillations at 3-4 years and 8-12 years, particularly since 1985 (Figure 1(b)). High and low years tend to occur in succession (e.g., 1971-75, 1977-78, 1979-81, 1984-87, 1988-90, 1994-95, 1999-2001). Figure 1(d) is the SeaWifs chlorophyll content averaged 1998-2007. It reveals high productivity in the southern Caribbean and nutrientpoor waters in the subtropical west Atlantic. Around the larger islands and coastal headlands are zones of enhanced phytoplankton accumulated from upwelling and nutrients carried in river run-off. Although the ocean color record is too short for composite analysis with respect to fish catch, it is studied to understand how productivity is modulated.

The seasonal cycle of environmental variables averaged over the Caribbean in the period 1998-2007 is presented in Figure 2. Both rainfall and near-surface temperature gradually increase to a maximum in late summer, with 


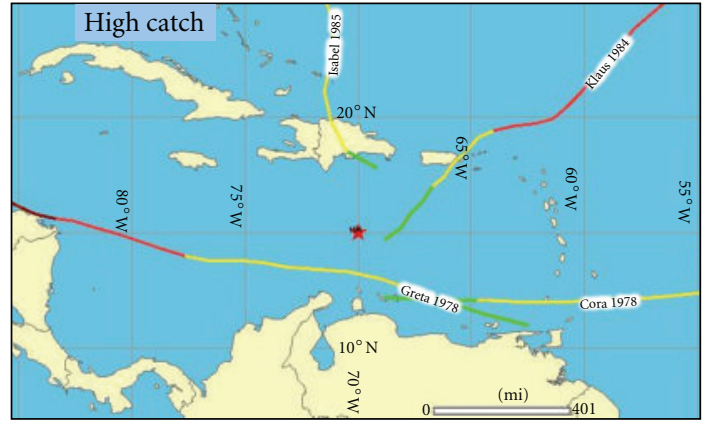

(a)

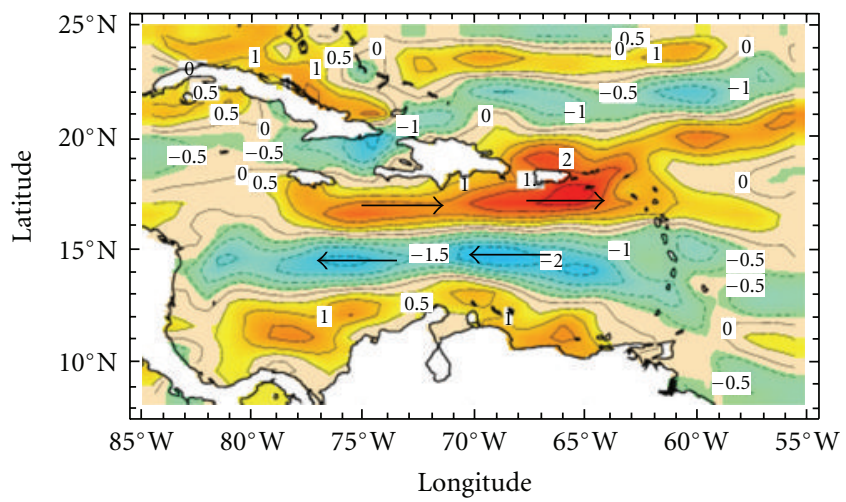

(c)

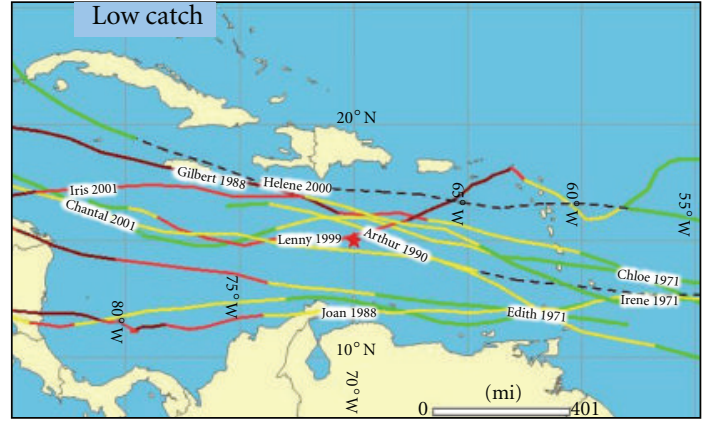

(b)

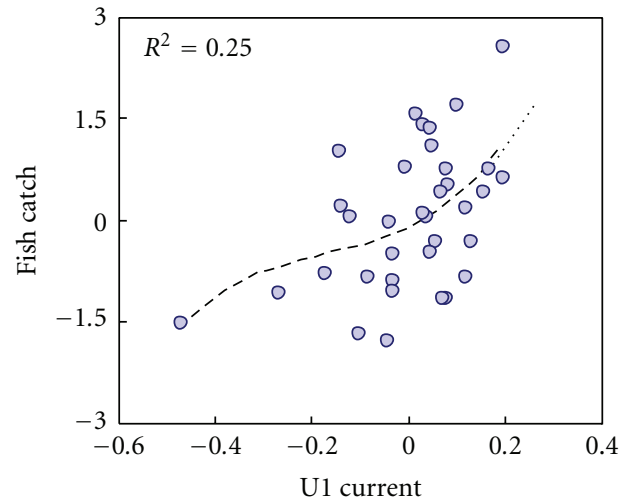

(d)

Figure 5: Composite tropical cyclone tracks for (a) high and (b) low-catch years (color = intensity, red > cat.2). (c) First mode of 0-200 m zonal current variability based on EOF analysis, and (d) its time score scatterplot with fish catch (dotted curve is best fit).

rain showing a secondary peak in spring (Figure 2(a)). Mixed layer depth remains near $50 \mathrm{~m}$ with a minimum in late summer. Currents are consistently westward with a slight northward component that is maximum in June and minimum in late summer. Zonal currents are slightly stronger in summer and winter than in transition seasons. There is mean downwelling across the Caribbean that inhibits productivity, particularly in winter (Figure 2(b)). Vertical motions are near zero in late summer. Wind stress is persistently westward with a weak southward component (Figure 2(c)). Trade winds are weakest in the hurricane season (August-October). Near-surface salinity is greatest at the end of the dry season (March-April) and falls rapidly in August as river run-off and rainfall increase. Chlorophyll content in both satellite and model display a single peak in mid-summer (June-July) when trade winds and south coast upwelling are enhanced (Figure 2(d)). Model-derived nitrate on the other hand, gradually declines during the year to a minimum in the hurricane season, inversely to rainfall. An environmental model for the seasonal cycle of chlorophyll was objectively formulated using mixed layer depth, temperature and meridional wind stress (Table 2(a), Figure 2(e)). The model explains two-thirds of the variance (significant at $90 \%$ confidence) but the peak is delayed 1-2 months. Productivity is more variable during summer, suggesting increased sensitivity to environmental forcing then. Developing an objective multivariate model for smoothed consecutive monthly chlorophyll anomalies (Table 2(b), Figure 2(f)), $45 \%$ of variance is explained (significant at $90 \%$ confidence). The model tracks interannual fluctuations using rainfall, temperature, meridional current and zonal wind stress. The association of cooler temperatures and enhanced trade winds with higher productivity is highlighted. There is a chlorophyll event in the summer of 2003 (cf. Figure 2(f)) related to the spread of upwelled water from Venezuela northward into a zone of lower salinity (cf. Figures 1(e) and 1(f)), where the Caribbean Current carries it westward.

\subsection{Composite Environmental Differences. Figure 3 presents} contrasts in the ocean environment with respect to fish catch. SST differences (Figure 3(a)) exhibit a cool plume extending across the southeastern Caribbean $\left(8^{\circ}-15^{\circ} \mathrm{N}, 55^{\circ}-65^{\circ} \mathrm{W}\right)$. In contrast the Bahamas and northern Cuba experience warmer SST. Thus a warm/north-cool/south gradient is superimposed during years of high fish catch. The composite sea surface height field displays a key feature: an eastwest $0.05 \mathrm{~m}$ ridge along $16^{\circ} \mathrm{N}$ stretching $2000 \mathrm{~km}$ from the Cayman Islands to Guadeloupe. It has a narrow north-south dimension of $200 \mathrm{~km}$, a frontal feature [61]. Apart from this ridge there are negative sea surface height differences off eastern Venezuela and in the Panama gyre. Anomalous currents tend to flow anticyclonically around the zonal sea surface ridge (Figure 3(c)), with enhanced westward flow on $15^{\circ} \mathrm{N}$ and weakened westward flow (eastward anomalies) on 
TABLE 2: Multi-variate regression of environmental variables onto the seasonal cycle of chlorophyll averaged over the Caribbean $1998-2007$.

(a) Using mixed layer depth, temperature and meridional wind stress. Multi-variate regression onto smoothed consecutive chlorophyll anomalies averaged over the Caribbean.

\begin{tabular}{lcccc}
\hline Adj R Sq & 0.66 & \multicolumn{2}{c}{ Regression statistics for seasonal Chl model } \\
\hline Std Error & 0.04 & SS & MS & $F$ \\
\hline ANOVA & deg.fr. & 0.04 & 0.01 & 7.99 \\
\hline Regression & 3.0 & 0.01 & 0.00 & $P$-value \\
Residual & 8.0 & Std Err & $t$ Stat & .01 \\
\hline & Coeff & 1.78 & -3.47 & .02 \\
\hline Intercept & -6.17 & 0.01 & 3.01 & .01 \\
mixL.D. & 0.02 & 0.06 & 3.73 & .01 \\
Temp & 0.23 & 1.94 & 3.70 & \\
Tau Y & 7.18 & &
\end{tabular}

(b) Using rainfall, temperature, meridional currents and zonal wind stress. Refer to Figures 2(e) and 2(f).

\begin{tabular}{lcccc}
\hline Adj R Sq & 0.45 & \multicolumn{3}{c}{ Regression statistics for anomaly Chl model } \\
\hline Std Error & 0.01 & SS & MS & $F$ \\
\hline ANOVA & deg.fr. & 0.02 & 0.01 & 26.14 \\
\hline Regression & 4.0 & 0.02 & 0.00 & $P$-value \\
Residual & 18.0 & Std Err & $t$ Stat & .15 \\
\hline & Coeff & 0.00 & 1.45 & .00 \\
\hline Intercept & 0.002 & 0.00 & 4.46 & .00 \\
Rain & 0.0005 & 0.00 & -8.09 & .00 \\
Temp & -0.04 & 0.38 & -5.22 & .00 \\
V cur & -1.97 & 0.28 & -7.51 & \\
Tau X & -2.08 & & & \\
\hline
\end{tabular}

$18^{\circ} \mathrm{N}$. This weakening of currents near the Antilles improves chances for the retention of food sources, larvae and juvenile fish [62]. The North Brazil Current is enhanced and may entrain nutrient-rich waters from the east Atlantic. Wind stress is anomalous westward particularly north of Venezuela (Figure 3(d)); the trade winds are stronger and more southeasterly than usual and promote northward Ekman transport and cooler SST. The temperature and salinity sections (Figures 3(e) and 3(f)) indicate the Caribbean is cool and fresh in the upper $100 \mathrm{~m}$ with respect to years of high fish catch. There is a warm salty layer that slopes downward to the north below $100 \mathrm{~m}$. Meridional currents and vertical motion differences reflect overturning near the South American coast (Figure 3(f)) and broad northward flow that spreads productive waters from Venezuela across the Caribbean.

Atmospheric contrasts associated with fish catch are illustrated in Figure 4. An upper level high pressure prevails over the tropical Atlantic while an upper level low pressure prevails over the east Pacific (not shown). The result is a meridional overturning atmospheric circulation (Figure 4(a)) that represents a weakening of the normal Hadley Cell with respect to high catch years; with upward motion north of the Antilles and sinking motion over South America. Atmospheric precipitable water is reduced over South America and enhanced in the northern Caribbean (Figure $4(\mathrm{~b})$ ). The climatic scenario corresponding with high fish catch is a wet/north-dry/south climatic gradient consistent with the warm/north-cool/south SST field. In the atmospheric height sections (Figures $4(\mathrm{c})$ and $4(\mathrm{~d})$ ) air temperatures and humidity over Venezuela are anomalous warm and dry, while in the Antilles zone (Hispanola) it is cool and moist with respect to high fish catch. The sea surface ridge on $16^{\circ} \mathrm{N}$ bisects opposing climate regimes. Warmer air temperatures in the $800 \mathrm{hPa}$ layer $\sim 11^{\circ} \mathrm{N}$ cap the trade winds, enhancing cyclonic curl and upwelling along the Venezuela coast. Thus ocean-atmosphere coupling is indicated in the composite difference fields.

\section{Discussion}

A fishery index developed from nine country records has been used to contrast environmental differences between high- and low-catch rates in the Caribbean. The index has pointed to a number of key features, most notably a cool SST plume and changes in the atmospheric Hadley cell which could suppress tropical cyclones. In Figures 5(a) and 5(b) hurricane tracks are given for the seven high- and low-catch years. Few hurricanes pass through the area in high catch years, while in low-catch years the Caribbean is inundated by hurricanes. Hurricanes influence "catchability" and "effort" due to the rough seas that are generated. Hurricanes typically bring swells $>6 \mathrm{~m}$ and can deepen the mixed layer $>100 \mathrm{~m}$, dispersing plankton and 
inhibiting feeding. Composite differences were found to be negligible over the Gulf Stream and Bermuda (not shown), so hurricanes do not "disappear" in years of high fish catch, they just shift out of the Caribbean due to cooler SST and corresponding changes in climate. It is noteworthy that Caribbean hurricanes have fluctuated with an 8-year cycle since $1970[63,64]$. Years with more hurricanes coincide with weaker trade winds and diminished coastal upwelling that inhibit the spread of productive waters.

The current patterns with respect to fish catch seen in Figure 3(c) reflect a southward shift of the Caribbean Current and anomalous eastward (decreased westward) flow in the Antilles islands. A question that arises is whether this current pattern is specific to fluctuations of the fishery, or is it a natural mode of ocean variability? This is addressed by decomposition of environmental fields into empirical orthogonal functions (EOF). The spatial loading pattern for the leading mode of zonal currents is illustrated in Figure 5(c) and corresponds with the vector field of Figure 3(c). The Caribbean Current alternates N-S of its mean axis $\left(-\mathrm{U}\right.$ on $14^{\circ} \mathrm{N},+\mathrm{U}$ on $\left.18^{\circ} \mathrm{N}\right)$, modulating the flow around Jamaica, Hispanola and the Anegada Passage, and thus chances for biological retention. Its scatterplot with fish catch (Figure 5(d)) indicates 25\% of variance explained, significant at $90 \%$ confidence with $34 \mathrm{df}$.

In summary, a key feature uncovered in this work based on a Caribbean fishery index is an anomalous sea surface ridge on $16^{\circ} \mathrm{N}$ that reflects anticyclonic recirculation during years of higher catch. South of the ridge, the westward Caribbean Current and North Brazil Current are strengthened. North of the ridge, anomalous eastward currents are found in the axis of the Antilles Islands (Jamaica, Hispanola, Puerto Rico, Guadeloupe). The ridge divides warm dry weather over Venezuela from cool wet weather over the northern Antilles, set up by an anomalous reversal of the atmospheric Hadley circulation. Trade winds and upwelling are stronger along the Venezuela coast in high catch years. The meridional ocean circulation (cf. Figure 3(f)) advects waters northward, infusing the Caribbean with more nutrients. Recirculation gyres along the north edge of the Caribbean Current (cf. Figure 3(c)) inhibit the loss of productive waters to the Yucatan passage, and promote retention in the Antilles zone. Hurricanes are rare during years of high fish catch, in conjunction with cooler SST. Fewer hurricanes offer chances for increased fishing effort in summer. Further work could be done to study the environmental modulation of fish catch per unit effort and dominant species; analysis of how the fish integrate environmental conditions over their lifespan; a comparison of local versus regional nitrification processes; and studies that relate global climatic trends to conditions that influence Caribbean fish catch.

\section{References}

[1] A. L. Gordon, "Circulation of the Caribbean Sea," Journal of Geophysical Research, vol. 72, pp. 6207-6223, 1967.

[2] S. J. Murphy, H. E. Hurlburt, and J. J. O’Brien, “The connectivity of eddy variability in the Caribbean Sea, the Gulf of Mexico, and the Atlantic Ocean," Journal of Geophysical Research, vol. 104, no. 1, pp. 1431-1453, 1999.

[3] C. A. Andrade and E. D. Barton, "Eddy development and motion in the Caribbean Sea," Journal of Geophysical Research, vol. 105, no. 11, pp. 26191-26201, 2000.

[4] W. E. Johns, T. L. Townsend, D. M. Fratantoni, and W. D. Wilson, "On the Atlantic inflow to the Caribbean Sea," DeepSea Research Part I, vol. 49, no. 2, pp. 211-243, 2002.

[5] J. Gyory, A. J. Mariano, and E. H. Ryan, "The Caribbean Current in Ocean Surface Currents," 2005, http://oceancurrents.rsmas.miami.edu/caribbean/caribbean. html.

[6] R. L. Molinari, M. Spillane, I. Brooks, D. Atwood, and C. Duckett, "Surface current in the Caribbean Sea as deduced from Lagrangian observations," Journal of Geophysical Research, vol. 86, pp. 6537-6542, 1981.

[7] L.-L. Fu and B. Holt, "Some examples of detection of oceanic mesoscale eddies by the Seasat synthetic-aperture radar," Journal of Geophysical Research, vol. 88, no. 3, pp. 1844-1852, 1983.

[8] T. H. Kinder, G. W. Heburn, and A. W. Green, "Some aspects of the Caribbean circulation," Marine Geology, vol. 68, no. 1-4, pp. 25-52, 1985.

[9] D. M. Fratantoni, "North Atlantic surface circulation during the 1990's observed with satellite-tracked drifters," Journal of Geophysical Research, vol. 106, no. 10, pp. 22067-22093, 2001.

[10] D. Roemmich, "Circulation in the Caribbean Sea: a resolved inverse problem," Journal of Geophysical Research, vol. 86, pp. 7993-8005, 1981.

[11] A. Hernandez-Guerra and T. M. Joyce, "Water masses and circulation in the surface layers of the Caribbean at $66 \circ$ W," Geophysical Research Letters, vol. 27, no. 21, pp. 3497-3500, 2000.

[12] J. T. Gunn and D. R. Watts, "On the currents and water masses north of the Antilles/Bahamas Arc," Journal of Marine Research, vol. 40, no. 1, pp. 1-18, 1982.

[13] T. N. Lee, W. E. Johns, R. J. Zantopp, and E. R. Fillenbaum, "Moored observations of western boundary current variability and thermohaline circulation at $26.5^{\circ} \mathrm{N}$ in the subtropical North Atlantic," Journal of Physical Oceanography, vol. 26, no. 6, pp. 962-983, 1996.

[14] G. L. Hitchcock, T. N. Lee, P. B. Ortner, S. Cummings, C. Kelble, and E. Williams, "Property fields in a Tortugas Eddy in the southern straits of Florida," Deep-Sea Research Part I, vol. 52, no. 12, pp. 2195-2213, 2005.

[15] W. J. Schmitz and W. S. Richardson, "On the transport of the Florida current," Deep-Sea Research, vol. 38, supplement, pp. 379-409, 1991.

[16] R. C. Wajsowicz, "A modified sverdrup model of the Atlantic and Carribbean circulation," Journal of Physical Oceanography, vol. 32, no. 3, pp. 973-993, 2002.

[17] W. D. Wilson and W. E. Johns, "Velocity structure and transport in the Windward Islands Passages," Deep-Sea Research Part I, vol. 44, no. 3, pp. 487-520, 1997.

[18] A. Alvera-Azcárate, A. Barth, and R. H. Weisberg, "The surface circulation of the Caribbean Sea and the Gulf of Mexico as inferred from satellite altimetry," Journal of Physical Oceanography, vol. 39, no. 3, pp. 640-657, 2009. 
[19] J. M. Leis, "The pelagic stage of reef fishes: the larval biology of coral reef fishes," in The Ecology of Fishes on Coral Reefs, P. F. Sale, Ed., pp. 183-230, Academic Press, San Diego, Calif, USA, 1991.

[20] L. W. Botsford, C. L. Moloney, A. Hastings et al., "The influence of spatially and temporally varying oceanographic conditions on meroplanktonic metapopulations," Deep-Sea Research Part II, vol. 41, no. 1, pp. 107-145, 1994.

[21] C. B. Paris and R. K. Cowen, "Direct evidence of a biophysical retention mechanism for coral reef fish larvae," Limnology and Oceanography, vol. 49, no. 6, pp. 1964-1979, 2004.

[22] J. D. Neilson and R. I. Perry, "Diel vertical migrations of marine fishes: an obligate or facultative process?" Advances in Marine Biology, vol. 26, pp. 115-168, 1990.

[23] H. H. Roberts, P. A. Wilson, and A. Lugo-Fernández, "Biologic and geologic responses to physical processes: examples from modern reef systems of the Caribbean-Atlantic region," Continental Shelf Research, vol. 12, no. 7-8, pp. 809-834, 1992.

[24] J. M. Shenker, E. D. Maddox, E. Wishinski, A. Pearl, S. R. Thorrold, and N. Smith, "Onshore transport of settlementstage Nassau grouper Epinephelus striatus and other fishes in Exuma Sound, Bahamas," Marine Ecology Progress Series, vol. 98, no. 1-2, pp. 31-43, 1993.

[25] R. K. Cowen and L. R. Castro, "Relation of coral reef fish larval distributions to island scale circulation around Barbados, West Indies," Bulletin of Marine Science, vol. 54, no. 1, pp. 228-244, 1994.

[26] G. Symonds, K. P. Black, and I. R. Young, "Wave-driven flow over shallow reefs," Journal of Geophysical Research, vol. 100, no. 2, pp. 2639-2648, 1995.

[27] E. D. Barton, J. Aristegui, P. Tett et al., "The transition zone of the Canary Current upwelling region," Progress in Oceanography, vol. 41, no. 4, pp. 455-504, 1998.

[28] R. S. Appeldoorn, D. A. Hensley, D. Y. Shapiro, S. Kioroglou, and B. G. Sanderson, "Egg dispersal in a Caribbean coral reef fish," Bulletin of Marine Science, vol. 54, no. 1, pp. 271-280, 1994.

[29] M. J. Milicich, "Dynamic coupling of reef fish replenishment and oceanographic processes," Marine Ecology Progress Series, vol. 110, no. 2-3, pp. 135-144, 1994.

[30] S. U. Sponaugle and R. K. Cowen, "Early life history traits and recruitment patterns of Caribbean wrasses (Labridae)," Ecological Monographs, vol. 67, no. 2, pp. 177-202, 1997.

[31] D. R. Robertson, S. E. Swearer, K. Kaufmann, and E. B. Brothers, "Settlement vs. environmental dynamics in a pelagic-spawning reef fish at Caribbean Panama," Ecological Monographs, vol. 69, no. 2, pp. 195-218, 1999.

[32] R. K. Cowen, "Larval dispersal and retention and consequences for population connectivity," in Coral Reef Fishes. Dynamics and Diversity in a Complex Ecosystem, P. F. Sale, Ed., pp. 149-170, Academic Press, San Diego, Calif, USA, 2002.

[33] J. L. Munro, V. C. Gaut, R. Thompson, and P. H. Reeson, "The spawning seasons of Caribbean reef fishes," Journal of Fish Biology, vol. 5, no. 1, pp. 69-84, 1973.

[34] P. L. Colin, "Reproduction of the Nassau grouper, Epinephelus striatus (Pisces: Serranidae) and its relationship to environmental conditions," Environmental Biology of Fishes, vol. 34, no. 4, pp. 357-377, 1992.
[35] P. J. S. Franks, "Sink or swim: accumulation of biomass on fronts," Marine Ecology Progress Series, vol. 82, pp. 1-12, 1992.

[36] W. M. Graham, J. G. Field, and D. C. Potts, "Persistent "upwelling shadows" and their influence on zooplankton distributions," Marine Biology, vol. 114, no. 4, pp. 561-570, 1992.

[37] P.S. Lobel and A.R. Robinson, "Reef fishes at sea: ocean currents and the advection of larvae," in The Ecology of Deep and Shallow Coral Reefs, M. L. Reaka, Ed., vol. 11 of NOAA Symposium Series for Undersea, pp. 29-38, Noaa's Undersea Research Program (NURP), Rockville, Md, USA, 1983.

[38] P. S. Lobel and A. R. Robinson, "Transport and entrapment of fish larvae by ocean mesoscale eddies and currents in Hawaiian waters," Deep Sea Research Part A, vol. 33, no. 4, pp. 483-500, 1986.

[39] S. U. Sponaugle and K. Grorud-Colvert, "Environmental variability, early life-history traits, and survival of new coral reef fish recruits," Integrative and Comparative Biology, vol. 46, no. 5, pp. 623-633, 2006.

[40] F. E. Muller-Karger, C. R. McClain, and P. L. Richardson, "The dispersal of the Amazon's water," Nature, vol. 333, no. 6168, pp. 56-59, 1988.

[41] J. M. Morrison and O. P. Smith, "Geostrophic transport variability along the Aves Ridge in the eastern Caribbean Sea during 1985-1986," Journal of Geophysical Research, vol. 95, pp. 699-710, 1990.

[42] C. B. Grimes and M. J. Kingsford, "How do riverine plumes of different sizes influence fish larvae: do they enhance recruitment?" Marine and Freshwater Research, vol. 47, no. 2, pp. 191-208, 1996.

[43] R. J. Allman and C. B. Grimes, "Growth and mortality of little tunny (Euthynnus alletferatus) larvae off the Mississippi River plume and Panama City, Florida," Bulletin of Marine Science, vol. 62, no. 1, pp. 189-197, 1998.

[44] A. Scotti and J. Pineda, "Plankton accumulation and transport in propagating nonlinear internal fronts," Journal of Marine Research, vol. 65, no. 1, pp. 117-145, 2007.

[45] A. R. Robinson, Eddies in Marine Science, Springer, New York, NY, USA, 1983.

[46] A. Okubo, "The role of diffusion and related physical processes in dispersal and recruitment of marine populations," in The Bio-Physics of Marine Larval Dispersal, P. W. Sammarco and M. L. Heron, Eds., pp. 5-32, American Geophysical Union, Washington, DC, USA, 1994.

[47] C. B. Limouzy-Paris, H. C. Graber, D. L. Jones, A. W. Ropke, and W. J. Richards, "Translocation of larval coral reef fishes via sub-mesoscale spin-off eddies from the Florida current," Bulletin of Marine Science, vol. 60, no. 3, pp. 966-983, 1997.

[48] S. U. Sponaugle and D. R. Pinkard, "Impact of variable pelagic environments on natural larval growth and recruitment of the reef fish Thalassoma bifasciatum," Journal of Fish Biology, vol. 64, no. 1, pp. 34-54, 2004.

[49] C. Yeung, D. L. Jones, M. M. Criales, T. L. Jackson, and W. J. Richards, "Influence of coastal eddies and counter-currents on the influx of spiny lobster, Panulirus argus, postlarvae into Florida Bay," Marine and Freshwater Research, vol. 52, no. 8, pp. 1217-1232, 2001.

[50] A. R. Emery, "Eddy formation from an oceanic island: ecological effects," Caribbean Journal of Science, vol. 12, pp. 121-128, 1972.

[51] D. Rissik, I. M. Suthers, and C. T. Taggart, "Enhanced zooplankton abundance in the lee of an isolated reef in the 
south Coral Sea: the role of flow disturbance," Journal of Plankton Research, vol. 19, no. 9, pp. 1347-1368, 1997.

[52] G. Basterretxea, E. D. Barton, P. Tett, P. Sangrá, E. NavarroPerez, and J. Arístegui, "Eddy and deep chlorophyl maximum response to wind-shear in the lee of Gran Canaria," Deep-Sea Research Part I, vol. 49, no. 6, pp. 1087-1101, 2002.

[53] R. Froese and D. Pauly, Eds., "FishBase," World Wide Web electronic publication, 2010, http://www.fishbase.org/.

[54] FAO (Food and Agriculture Organization), "Marine fishery resources of the Antilles: Lesser Antilles, Puerto Rico and Hispaniola," Tech. Rep. 326, FAO Fisheries, Jamaica, Cuba, 1993.

[55] R. Mahon and H. A. Oxenford, "Precautionary assessment and management of dolphinfish in the Caribbean," Scientia Marina, vol. 63, no. 3-4, pp. 429-438, 1999.

[56] M. J. Paddack, J. D. Reynolds, C. Aguilar et al., "Recent regionwide declines in Caribbean reef fish abundance," Current Biology, vol. 19, no. 7, pp. 590-595, 2009.

[57] E. Kalnay, M. Kanamitsu, R. Kistler et al., "The NCEP/NCAR 40-year reanalysis project," Bulletin of the American Meteorological Society, vol. 77, no. 3, pp. 437-471, 1996.

[58] J. Sheffield, G. Goteti, and E. F. Wood, "Development of a 50year high-resolution global dataset of meteorological forcings for land surface modeling," Journal of Climate, vol. 19, no. 13, pp. 3088-3111, 2006.

[59] J. A. Carton and B. S. Giese, "A reanalysis of ocean climate using simple ocean data assimilation (SODA)," Monthly Weather Review, vol. 136, no. 8, pp. 2999-3017, 2008.

[60] W. W. Gregg, "Assimilation of SeaWiFS ocean chlorophyll data into a three-dimensional global ocean model," Journal of Marine Systems, vol. 69, no. 3-4, pp. 205-225, 2008.

[61] E. Wolanski and W. M. Hamner, "Topographically controlled fronts in the ocean and their biological influence," Science, vol. 241, no. 4862, pp. 177-181, 1988.

[62] F. E. Werner, J. A. Quinlan, B. O. Blanton, and R. A. Luettich Jr., "The role of hydrodynamics in explaining variability in fish populations," Journal of Sea Research, vol. 37, no. 3-4, pp. 195212, 1997.

[63] M. R. Jury, "A quasi-decadal cycle in Caribbean climate," Journal of Geophysical Research, vol. 114, no. 13, Article ID D13102, 8 pages, 2009.

[64] M. R. Jury and D. B. Enfield, "Environmental patterns associated with active and inactive Caribbean hurricane seasons," Journal of Climate, vol. 23, no. 8, pp. 2146-2160, 2010. 

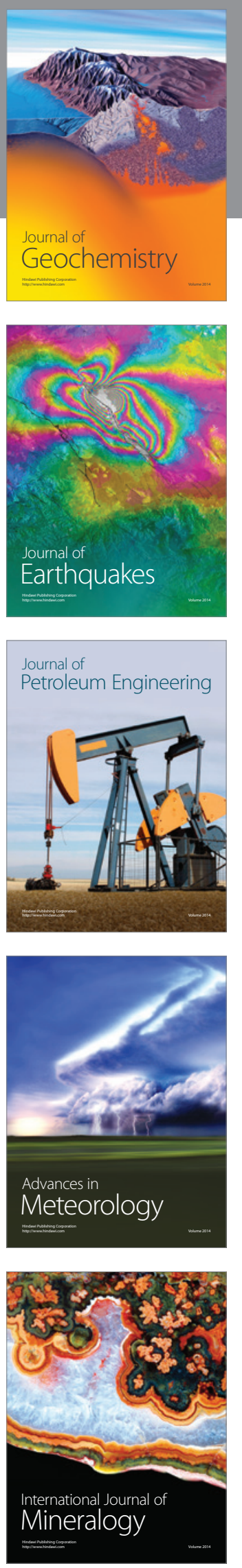
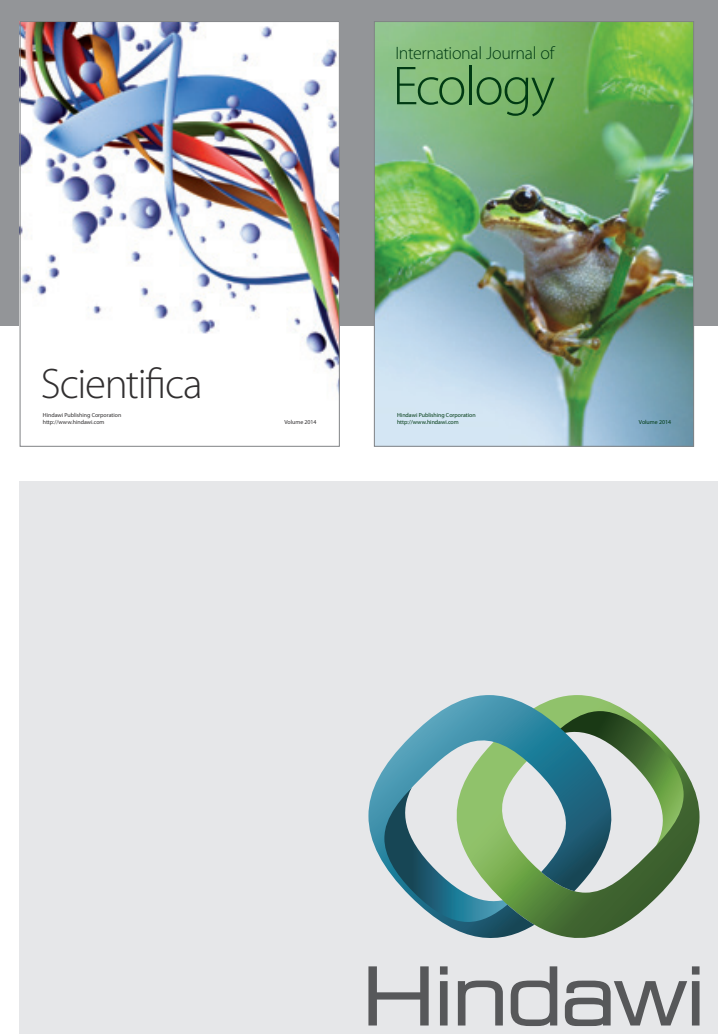

Submit your manuscripts at http://www.hindawi.com
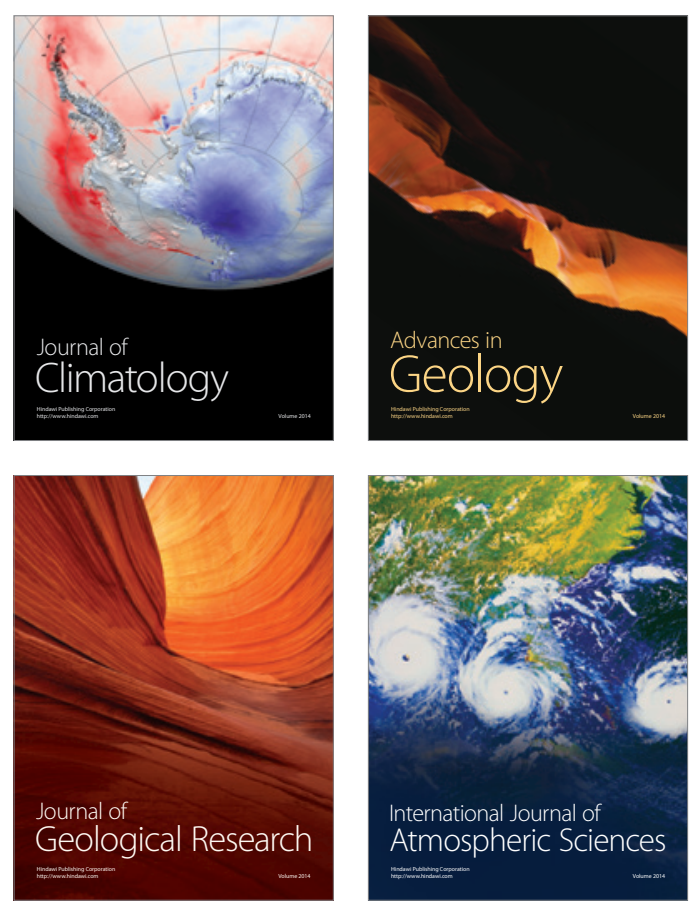
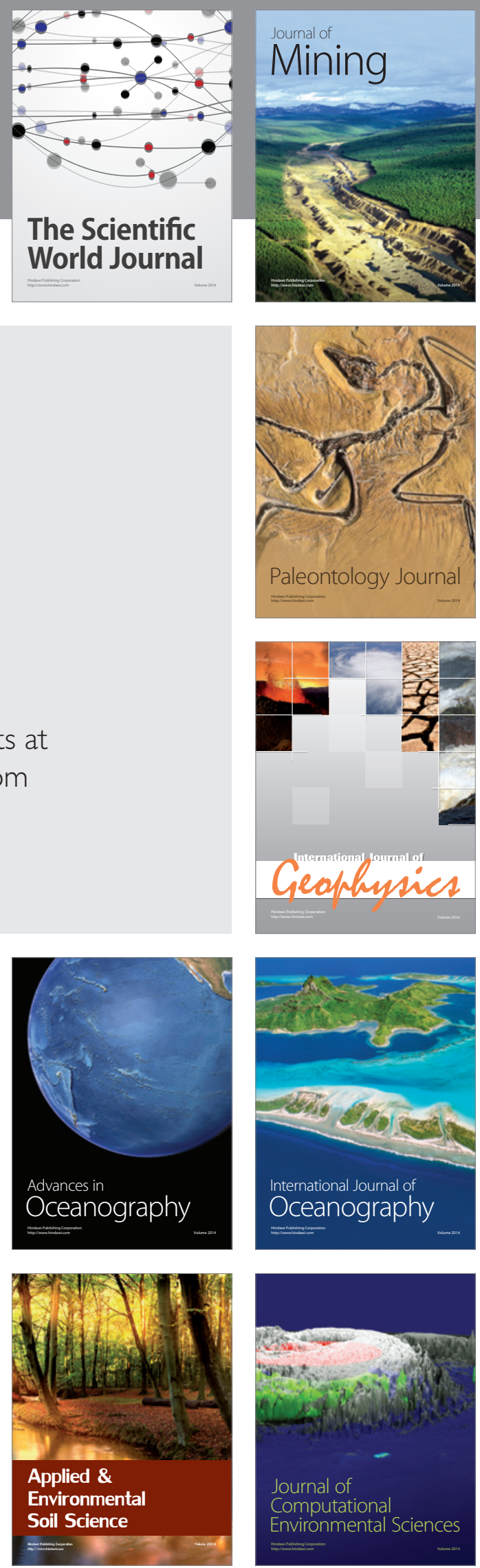